Article

\title{
Experimental Study of Uniaxial Compressive Strength (UCS) Distribution of Hydraulic Backfill Associated with Segregation
}

\author{
Jean Béket Dalcé, Li Li@ and Pengyu Yang *,+† \\ Research Institute on Mines and Environment, Department of Civil, Geological and Mining Engineering, \\ École Polytechnique de Montréal, C.P. 6079, Succursale Centre-Ville, Montréal, QC H3C 3A7, Canada; \\ jean-beket.dalce@polymtl.ca (J.B.D.); li.li@polymtl.ca (L.L.) \\ * Correspondence: pengyu.yang@polymtl.ca \\ + Current address: School of Architecture and Civil Engineering, Xi'an University of Science and Technology, \\ 58 Yanta Rd., Xi'an 710054, China.
}

Received: 1 January 2019; Accepted: 22 February 2019; Published: 28 February 2019

check for updates

\begin{abstract}
Stope backfilling with mine wastes has become a common practice in underground mines worldwide. Despite the increasing popularity in paste and rock fills, hydraulic fill made of classified mill tailings or sands remains commonly used in many mines. When such a slurried material is placed in a mine stope, a phenomenon known as segregation can take place associated with the quick drainage and consolidation of the hydraulic fill, thereby leading to a heterogeneous fill mass. While numerous publications have focused on the alleviation of segregation, there are few studies on the characterization of the distribution of geotechnical properties within hydraulic fill due to segregation. It is particularly scarce to quantify the spatial variation of the segregation and the resulting geotechnical properties after a backfill is placed in an opening. There is also a gap to quantitatively describe the degree of segregation using an appropriate expression or definition. The aim of this study is to investigate the effect of the segregation on the spatial variation of the geotechnical properties of hydraulic fill. Laboratory tests were performed with the cemented hydraulic backfill prepared with columns of different heights. The experimental results indicate that the segregation takes place and the resulting physical and mechanical properties can vary throughout the columns for samples higher than twice of the standard size. These results also indicate that the mechanical properties of a hydraulic fill obtained in a laboratory following the current practice with standard samples may not be representative of the fill mass placed in mine stopes. Expressions are proposed to quantify the degree of segregation associated with the spatial variation of particle sizes of mine hydraulic backfill.
\end{abstract}

Keywords: hydraulic backfill; segregation; degree of segregation; unconfined compression strength; laboratory tests

\section{Introduction}

Stope filling with mine wastes has become a common practice in underground mines across the world. Mine backfill can provide a safer working platform or space, improve the ground stability, increase ore recovery, reduce ore dilution, and improve the efficiency of ventilation [1-17]. The use of mill tailings as backfill materials can also decrease the surface disposal of mine wastes. The environmental impact due to the mine wastes [18,19] and the geohazards associated with their surface storage facilities can thus be reduced [20]. Similarly, stope filling with municipal wastes can become an interesting solution to reduce environmental impact associated with the increasing 
generation of municipal wastes, improve ground stability of mine stopes, and reduce subsidence of ground surface above mine cavities [21].

Despite the popularity of paste fill, hydraulic fill (HF) remains widely used in Australia, Canada, China, Poland, and elsewhere [22,23]. A backfill can be classified as paste fill when the following two criteria are met [3]: (1) the backfill contains at least $15 \%$ of particles smaller than $20 \mu \mathrm{m}$; (2) the fill does not bleed water upon deposition. Nowadays, the first criterion can be satisfied by almost all mill (full) tailings produced from hard rock mines [24], due to finer and finer mill tailings resulted from improved process technology. In many cases, the second criterion is ignored so that a backfill made of full tailings (called unclassified tailings in China) is generally called paste backfill.

As a saturated or over-saturated granular material would always bleed water following the self-weight consolidation [25-27], a backfill meeting the aforementioned second criterion of paste backfill is probably unsaturated [28] and cohesive (due to suction). Its transportation by pipelines can thus be difficult. In practice, excessive water is commonly added to increase the fill's flowability. Pipeline wash-out before and after each filling cycle is another reason for the increased water content of the backfill. All these planned or unplanned water additions tend to saturate or over saturate the backfill, thereby failing the second criterion of paste backfill. This type of backfill is then sometimes called hydraulic backfill or pulp backfill (to distinguish with the conventional hydraulic backfill).

Hydraulic fill is made of sand or deslimed mill tailings, or a mixture of both [29-31]. A hydraulic backfill should not contain more than $10 \%$ of particles smaller than $10 \mu \mathrm{m}$ [3]. In most cases, a portion of fine particles has to be removed through hydrocyclone or other desliming operations. This is the targeted hydraulic backfill (called classified backfill in China) in this study. To ease its pipeline transportation, HF usually contains a lot of water with solids content varying between $65 \%$ and $75 \%$ [2,3,32]. Binders can be added to produce a cemented hydraulic fill (CHF).

As the content of fine particles is low, hydraulic fill usually has a relatively high hydraulic conductivity, typically in the order of magnitude between $10^{-5} \mathrm{~m} / \mathrm{s}$ and $10^{-6} \mathrm{~m} / \mathrm{s}[2,3,33-36]$. Upon deposition in a stope, the drainage and consolidation can take place quickly within HF, leading to the bleeding of free water from the barricades and ponding on the top surface of fill. The relatively high velocity of upward flow can drive fine particles upward while the downward flow can accelerate the settlement of HF particles. Subsequently, the coarse particles generally tend to settle down, whereas the fine particles can migrate with the water flow up toward the top of the backfill or down toward the bottom of the stope, depending on their initial position and drainage water flow direction. This results in a heterogeneous fill mass, generally with more fine particles in the upper part and more coarse particles in the lower part. A phenomenon known as segregation occurs.

Segregation is defined as a spatial variation of the physical properties of a material $[37,38]$. In civil engineering, the segregation of concrete has been well studied [39-43]. In mining engineering, segregation is commonly observed in tailings ponds, where more coarse particles are located near the discharge points while more fine particles migrate farther [44-46]. Segregation is also well documented in pipeline transportation $[3,29,47-51]$.

In mine backfilled stopes, the heterogeneity of hydraulic backfill associated with the segregation has been frequently reported [22,52-64]. Many efforts have been devoted to reducing the segregation by adding flocculent substance $[53,57,63,65,66]$. However, few studies have focused on the characterization of segregation and its effect on the physical and mechanical properties of the backfill deposited in the stope. It is particularly uncommon to quantify the spatial variation of the segregation and the resulting geotechnical properties after a backfill is deposited in an opening. There is also a gap in quantitatively describing the degree of segregation using an appropriate expression or definition. In this paper, the segregation (and the resulting spatial variation of physical and mechanical properties) of a CHF is investigated using laboratory tests performed on CHF samples prepared in columns of different heights. Expressions are proposed to quantitatively define the degree of segregation associated with the spatial variation of particle sizes of hydraulic backfill. 


\section{Material and Test Procedure}

Figure 1 shows the test program used to investigate the segregation of a hydraulic backfill. The column molds are made of Plexiglas columns ( $5 \mathrm{~cm}$ in internal diameter) of 15, 25, 50, and $95 \mathrm{~cm}$ high, respectively. Backfill samples were prepared in such a way that they would finally settle to 10 , 20 , 40, and $80 \mathrm{~cm}$ high, respectively; calculations were based on an analytical solution developed for estimating the heights of pond and settled backfill placed in columns, inspired from that of Yang and Li [67] developed for rectangular cross-section stopes.

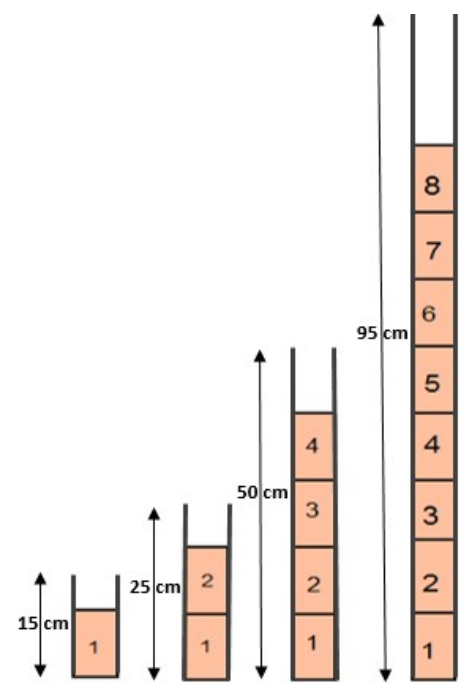

Figure 1. Illustration of cemented hydraulic fill (CHF) samples prepared in four columns; the number indicates the position of each sample of $10 \mathrm{~cm}$ high.

The solids of the HF are composed by $80 \%$ sands (deslimed by sieving) and $20 \%$ mill tailings (from a mine located in the Abitibi region of Quebec, Canada). The solid mixture has a specific gravity of 2.69, a maximum void ratio $e_{\max }$ of 0.72 , a minimum void ratio $e_{\min }$ of 0.36 , a porosity $n$ ranging between $26 \%$ and $42 \%$, an optimum water content $w_{\text {opt }}$ of $11.8 \%$, and a maximum dry unit weight $\gamma_{\mathbf{d}}$ of $19.35 \mathrm{kN} / \mathrm{m}^{3}$. Figure 2 shows the particle size distribution of the sand-tailings mixture, which has $5 \%$ of particles smaller than $10 \mu \mathrm{m}, 10 \%$ of particles passing $31 \mu \mathrm{m}, 50 \%$ of particles smaller than $214 \mu \mathrm{m}$, and a coefficient of uniformity of 8.3. More details of the physical properties of the mixture are summarized in Table 1. The mixture is a well graded non-plastic silty sand (SM) based on the Unified Soil Classification System classification.

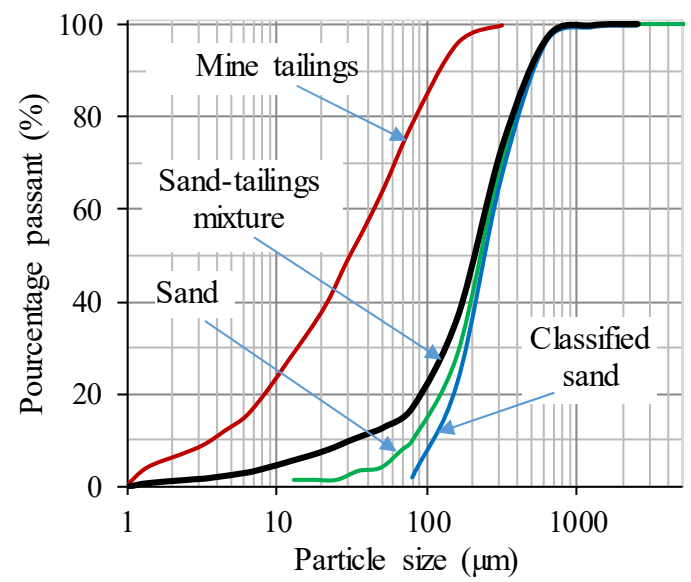

Figure 2. Particle size distribution of the sand-tailings mixture used to produce cemented hydraulic fill (CHF). 
Table 1. Physical characteristics of the sand-tailings mixture used to produce CHF.

\begin{tabular}{cc}
\hline Physical Properties & Values \\
\hline Specific gravity & 2.69 \\
Content of particles $<10 \mu \mathrm{m}(\%)$ & 5 \\
$D_{10}(\mu \mathrm{m})$ & 31 \\
$D_{30}(\mu \mathrm{m})$ & 131 \\
$D_{50}(\mu \mathrm{m})$ & 214 \\
$D_{60}(\mu \mathrm{m})$ & 257 \\
$D_{90}(\mu \mathrm{m})$ & 533 \\
Coefficient of uniformity $\left(C_{\mathrm{u}}\right)$ & 8.3 \\
Coefficient of curvature $\left(C_{\mathrm{c}}\right)$ & 2.2 \\
Maximum void ratio $\left(e_{\max }\right)$ & 0.72 \\
Minimum void ratio $\left(e_{\min }\right)$ & 0.36 \\
Optimum water content $w_{\mathrm{opt}}(\%)$ & 11.8 \\
Porosity $n(\%)$ & $26-42$ \\
Maximum dry unit weight $\gamma_{\mathrm{d}}\left(\mathrm{kN} / \mathrm{m}^{3}\right)$ & 19.35 \\
\hline
\end{tabular}

Ordinary Portland cement (type 10) was used at a ratio of 1:20 (sand-tailings mixture) to produce a CHF with a cement content of $5 \%$. De-aired water was used to make a CHF with solids content of $70 \%$. The saturated hydraulic conductivity of the CHF is measured to be $2.41 \times 10^{-6} \mathrm{~m} / \mathrm{s}$ (constant head) and $2.35 \times 10^{-6} \mathrm{~m} / \mathrm{s}$ (variable head) after $24 \mathrm{~h}$ of saturation [68].

Figure 3 shows the preparation technique adopted in this study, which is mostly like a combined method of water pluviation and slurry deposition [69]. The sample was prepared following the steps below:

(1) The sand-tailings mixture and the cement are mixed and well agitated to make a homogeneous CHF material.

(2) The CHF solids were slowly poured into a mold which was first filled with de-aired water. The weights of solids and de-aired water were based on the solid content of CHF, to guarantee that the height of the consolidated fill is close to the expected height after 28 days' curing.

(3) After the sedimentation of the CHF particles, the mold was agitated vigorously by shaking and turning the column upside-down.

(4) The column was then placed on a horizontal surface to allow the settlement of the CHF particles under room temperature $\left(22^{\circ} \mathrm{C}\right)$ for 28 days. The base of the column is impervious, with no drainage allowed at the base.

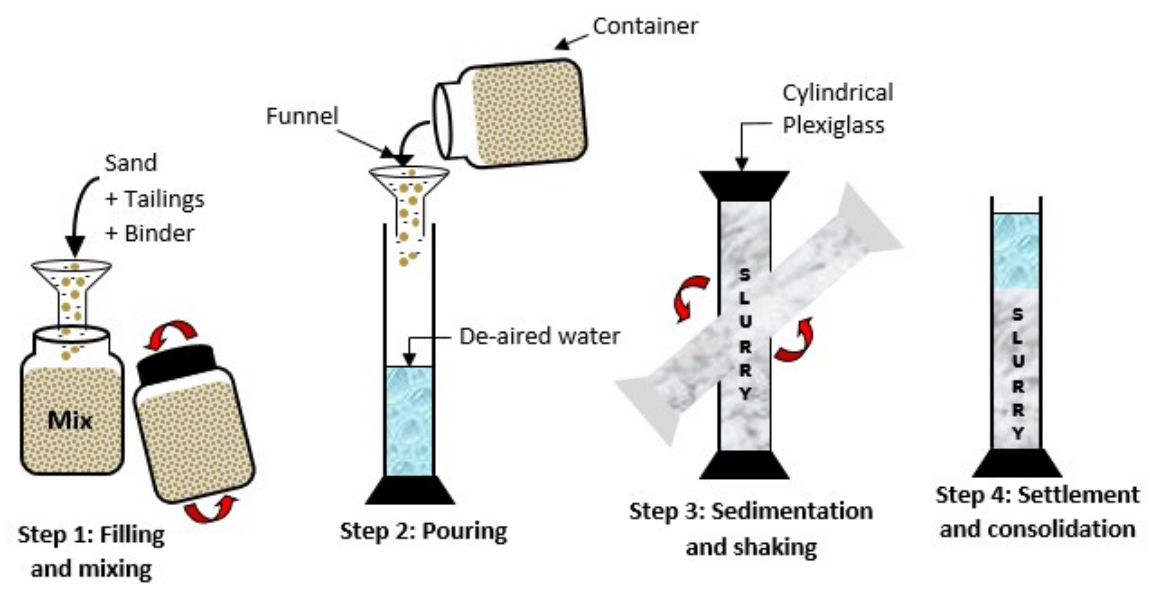

Figure 3. Illustration of the deposition method of cemented hydraulic fill (CHF) (adapted with the permission from [Carraro, J.; Prezzi, M.], [Geotechnical Testing Journal], published by [ASTM International] [69]). 
Figure 4 shows the CHF specimens within columns of different heights. Ponding can be observed on the top surface of the backfill due to upward drainage. Consequently, the thickness of the backfill was reduced due to self-weight consolidation.

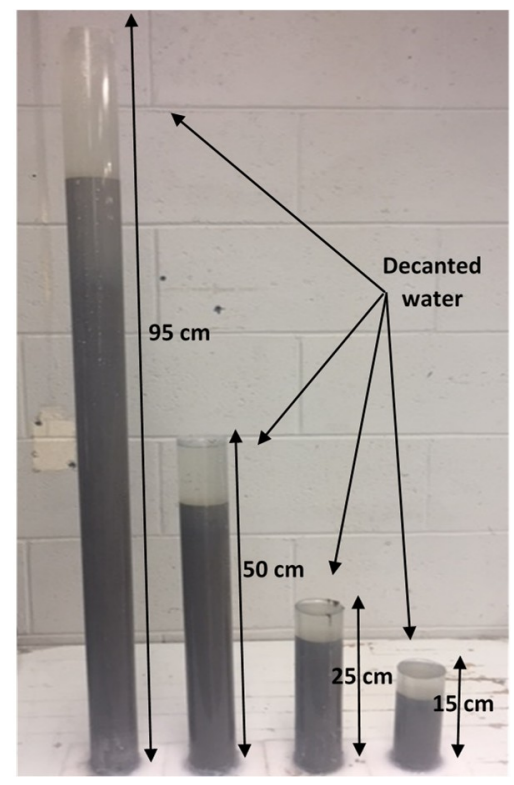

Figure 4. Illustration of cemented hydraulic fill placed in different columns after complete settlement.

At the curing time of 28 days, the columns were cut into $10 \mathrm{~cm}$ long specimens with a rock cutting saw machine. The CHF specimens were taken out from the tubes by applying a pressure on one end of the CHF. One, two, four, and eight samples of $10 \mathrm{~cm}$ high were obtained with the columns of $15,20,50$, and $95 \mathrm{~cm}$ high, respectively. The samples of $5 \mathrm{~cm}$ in diameter and $10 \mathrm{~cm}$ high were tested to measure their uniaxial compressive strength (UCS), with each test repeated three times. The test program thus included 45 unconfined compression tests. The tests were performed following the ASTM (American Society for Testing and Materials) standard developed for cylindrical concrete specimens [70]. The axial loading was applied by controlling the strain rate at a value of $1 \mathrm{~mm} / \mathrm{min}$.

After the uniaxial compressive tests, the crushed samples were collected to measure the particle size distribution of the backfill located at different elevations of each column. The sieve analysis was performed after destroying and grinding the samples into a powder-like material. The portion of fine particles smaller than $80 \mu \mathrm{m}$ was then subjected to sedimentometer tests. Two additional columns of $10 \mathrm{~cm}$ and $80 \mathrm{~cm}$ high were added to define the variation of the porosity and density of the CHF due to segregation. The samples are $2 \mathrm{~cm}$ high for the $10 \mathrm{~cm}$ column (resulting in 5 samples), and $5 \mathrm{~cm}$ for the $80 \mathrm{~cm}$ column (resulting in 15 samples). More details can be found in Dalcé [71] for the measurement of dry density and porosity.

\section{Test Results and Interpretation}

The particle size distribution, porosity, and dry density have been determined for different layers of settled backfill in the columns. Typical results are presented in the following.

Figure 5 illustrates the variation of the particle size distribution curves of the CHF after a curing time of 28 days for different columns. Layer 1 represents the base layer of the column while Layers 2 , 3 , and so on represent the layers at higher elevations. For the column of $10 \mathrm{~cm}$ (Figure $5 \mathrm{a}$ ), the addition of binder in the HF increases the percentage of the fine particles $(<80 \mu \mathrm{m})$, but has little effect on the portion of the coarse particles. The $D_{10}$ of the $\mathrm{CHF}$ reduced to $25 \mu \mathrm{m}$, compared to $31 \mu \mathrm{m}$ of the HF (see Figure 2 and Table 1). This increase in the fine particle portion can affect the hydraulic properties of the backfill [29]. 


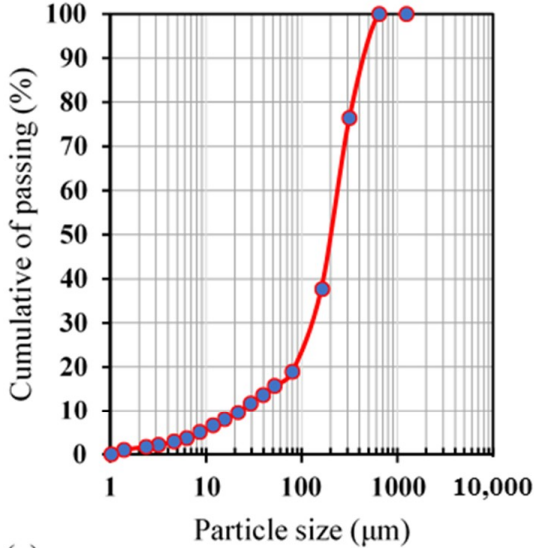

(a)

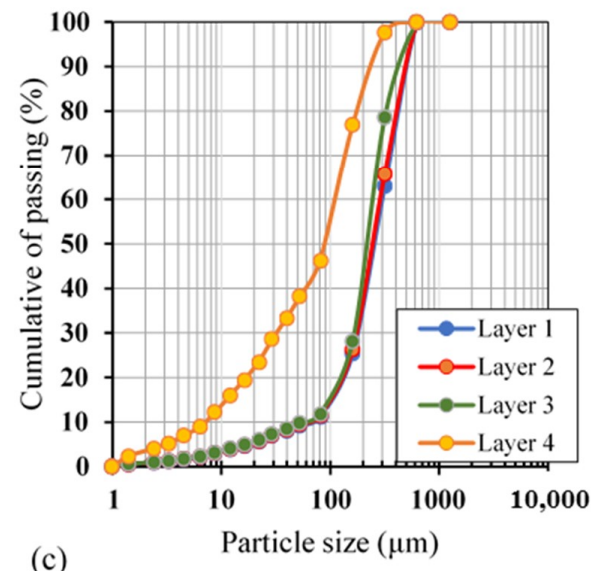

(c)
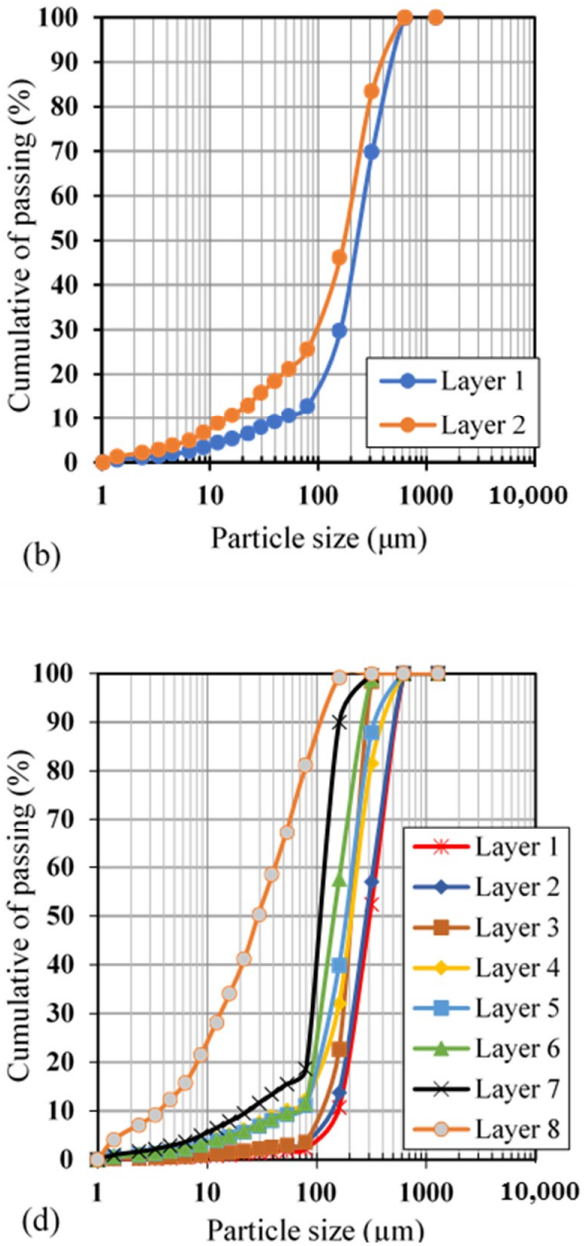

Figure 5. Particle size distributions of different layers of cemented hydraulic fill (CHF) after settlement and curing: (a) $10 \mathrm{~cm}$; (b) $(20 \mathrm{~cm}$ ); (c) $40 \mathrm{~cm}$; (d) $80 \mathrm{~cm}$ (Layers 1 to 8 indicate the locations of the layers from the base to the top of a backfilled column).

For the column of $20 \mathrm{~cm}$ (Figure 5b), two grain size distributions curves were obtained with the lower (Layer 1) and upper (Layer 2) samples. It can be seen that the CHF of Layer 1 is quite coarse with a $D_{10}$ close to that of the HF. However, the content of fine particles of Layer 2 increases significantly with a $D_{10}$ close to $10 \mu \mathrm{m}$, compared to $31 \mu \mathrm{m}$ of the HF (see Figure 2 and Table 1).

For the column of $40 \mathrm{~cm}$ (Figure 5c), Layers 1, 2, and 3 show almost similar grains size distribution, while Layer 4 represents fine material with $46.2 \%$ of particles smaller than $80 \mu \mathrm{m}$.

For the column of $80 \mathrm{~cm}$ (Figure $5 \mathrm{~d}$ ), the particle size distribution curves show that the content of fine particles generally increases from the bottom to the top of the settled backfill. The two bottom layers (Layers 1 and 2) are the coarsest with a $D_{10}$ close to $150 \mu \mathrm{m}$, while the two top layers (Layers 7 and 8$)$ are the finest with a $D_{10}$ of $3.5 \mu \mathrm{m}$ and more than $80 \%$ of fine particles $(<80 \mu \mathrm{m})$. These results indicate that the very coarse $\mathrm{CHF}$, classified as a silty sand (SM), has changed to a clean sand at the bottom, or a sandy silt (ML) on the top, or something intermediate between the clean sand and ML between the bottom and the top, depending on the sample positions (elevations). An upward migration of fine particles occurred. Accordingly, an initially homogenous slurried backfill ended by the formation of a heterogeneous material due to the fluidization segregation. In addition, the considerable difference between the particle size distribution curve of the top layer (Layer 8) and those of the other layers (Layers 1 to 7 ) indicates that Layer 8 probably contains much more particles of cement and thus has a higher cement content than Layers 1 to 7 . This is confirmed by the strength test results shown below. 
From the different particle size distribution curves shown in Figure 5, it is noted that the degree of segregation and the migration of fine particles (including cement) increase as the size of the samples increases. This clearly indicates that the test results obtained with standard test samples are not representative of those of CHF mass in mine stopes.

Figure 6 shows the variation of the $D_{50}$ (size of particles 50\% passing) along the height of the settled backfill within the columns of $20 \mathrm{~cm}$ (Figure 6a), $40 \mathrm{~cm}$ (Figure 6b), and $80 \mathrm{~cm}$ (Figure 6c), respectively. For the column of $10 \mathrm{~cm}$, the $D_{50}$ is close to the HF shown in Figure $5 \mathrm{a}$. For the column of $20 \mathrm{~cm}$ (Figure 6a), the $D_{50}$ decreases from bottom to top layers with $230 \mu \mathrm{m}$ for Layer 1 and $180 \mu \mathrm{m}$ for Layer 2. For the column of $40 \mathrm{~cm}$ (Figure 6b), one sees a slight decrease in the $D_{50}$ of the three lower layers from the bottom toward the top with an average value of $235 \mu \mathrm{m}$. A significant decrease of the $D_{50}$ is observed for the top layer with a value of $90 \mu \mathrm{m}$. For the column of $80 \mathrm{~cm}$ (Figure $6 \mathrm{c}$ ), a clear general trend can be seen with a decrease of the $D_{50}$ as the elevation of the layer increases.
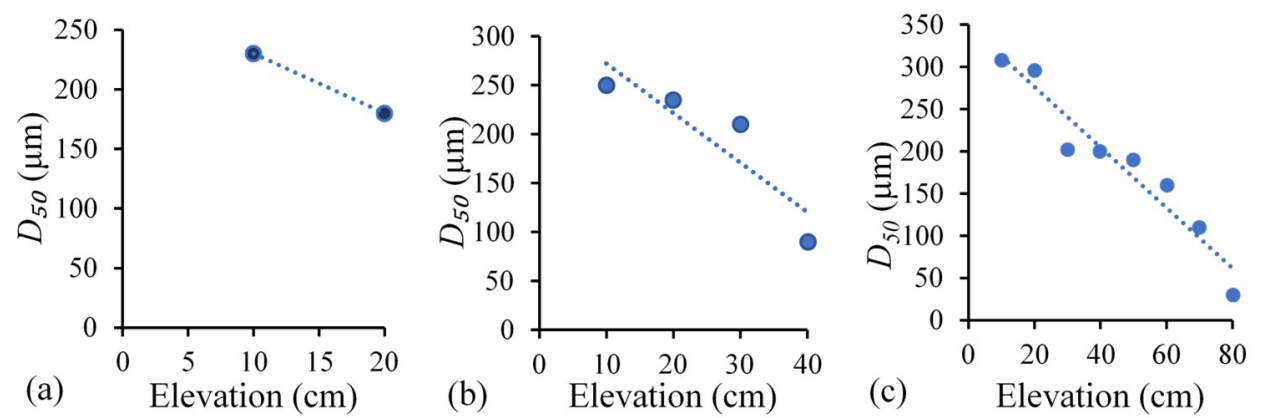

Figure 6. Variation of the $D_{50}$ (size of particles $50 \%$ passing) along the height of settled backfill for different backfilled columns: (a) $20 \mathrm{~cm}$, (b) $40 \mathrm{~cm}$, and (c) $80 \mathrm{~cm}$; the elevation measured from the bottom of the columns.

Figure 7 demonstrates the variation of the porosity $n$ along the height of the settled backfill of the columns $10 \mathrm{~cm}$ and $80 \mathrm{~cm}$ high, respectively. As an alternative of the void ratio, the variation of the porosity can partly reflect the effect of segregation on the geotechnical properties of the CHF. For the column of $10 \mathrm{~cm}$ (Figure 7a), the porosity of the three lower layers of measurement is almost the same with a value of 0.3 . An increase was observed for the two top layers of measurement with a value of 0.35 at the top of the fill. For the column of $80 \mathrm{~cm}$ (Figure $7 \mathrm{~b}$ ), the porosity remains almost constant along the height between $5 \mathrm{~cm}$ and $60 \mathrm{~cm}$ with a value of around 0.36 . Near the top between $65 \mathrm{~cm}$ and $75 \mathrm{~cm}$ of the settled backfill, the porosity becomes much larger with a value of 0.49 for the top layer. These results indicate that the top layers of the settled backfill are more porous than the lower layers. These results are in line with those reported by Potvin et al. [3] and Sivakugan et al. [72], who reported some porosity values in the range of 0.36 to 0.49 for settled hydraulic backfill. It should be mentioned that the variation of dry density is consistent with the measured values of porosity shown in Figure 7.
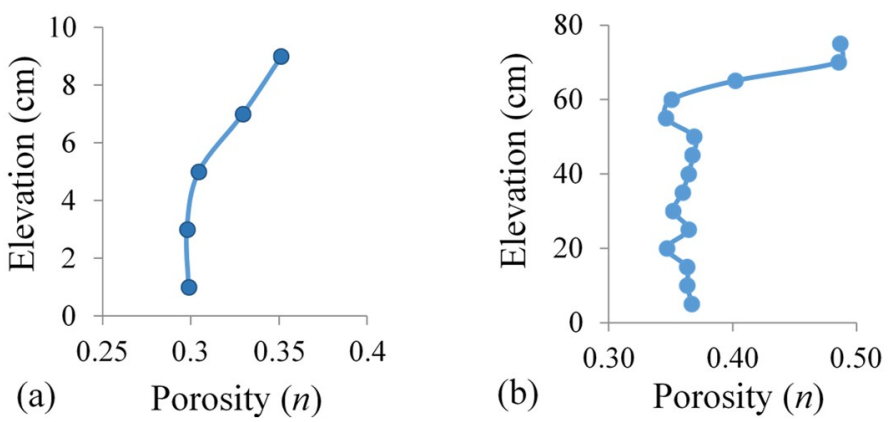

Figure 7. Variation of the porosity along the height of settled backfill for different backfilled columns: (a) $10 \mathrm{~cm}$; (b) $80 \mathrm{~cm}$; the elevation measured from the bottom of the columns. 
Figure 8 shows the variation of the uniaxial compressive strength (UCS) along the height of backfilled columns (note that the abscissa is elevation interval, not elevation). For each height group of the settled CHF specimens, three columns were tested. The force obtained was converted to pressure as a function of the diameter of the sample. Despite dispersion, the repeatability of the UCS results is generally quite good at each height of the three tested specimens. For the 10-cm-high samples, the measured UCS varies between $92 \mathrm{kPa}$ and $141 \mathrm{kPa}$ with an average of $121 \mathrm{kPa}$. For samples taken from the 20-cm-high columns, the UCS of the lower part (between $0 \mathrm{~cm}$ and $10 \mathrm{~cm}$ ) are almost the same as that of the 10-cm-high samples, while the upper part (between $10 \mathrm{~cm}$ and $20 \mathrm{~cm}$ ) exhibit slightly lower UCS values. For the $40-\mathrm{cm}$-high samples, the bottom part (between $0 \mathrm{~cm}$ and $10 \mathrm{~cm}$ ) shows very little UCS ranging between $9 \mathrm{kPa}$ and $15 \mathrm{kPa}$ with an average of $12 \mathrm{kPa}$. From $10 \mathrm{~cm}$ to 40 $\mathrm{cm}$, the samples have larger UCS values (close to that of the upper part of the 20-cm-high columns). The general trend of UCS distribution along the 80-cm-high samples is quite similar to the 40-cm-high columns. From $0 \mathrm{~cm}$ to $20 \mathrm{~cm}$, the samples show very similar UCS values to that of the bottom (between $0 \mathrm{~cm}$ and $10 \mathrm{~cm}$ ) of the $40-\mathrm{cm}$-high column. From $20 \mathrm{~cm}$ to $70 \mathrm{~cm}$, the UCS values are close to those of the $10 \mathrm{~cm}$ and $20 \mathrm{~cm}$ columns. The top layer between $70 \mathrm{~cm}$ and $80 \mathrm{~cm}$ shows a considerable higher strength than the other part of columns with an average UCS of $370 \mathrm{kPa}$.

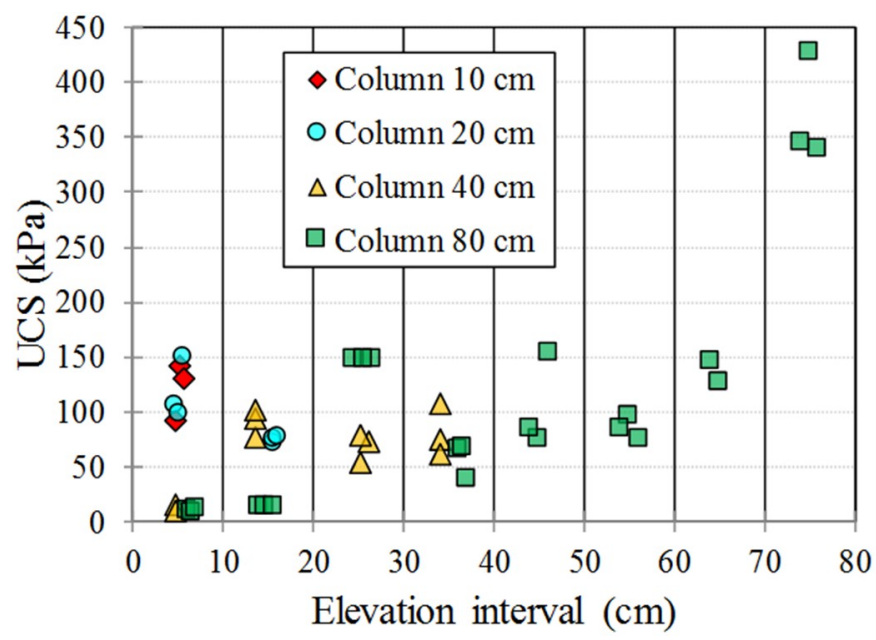

Figure 8. Variations of uniaxial compressive strength of cemented hydraulic fill samples taken from columns of $10 \mathrm{~cm}, 20 \mathrm{~cm}, 40 \mathrm{~cm}$, and $80 \mathrm{~cm}$ height; the elevation measured from the bottom of the columns.

The results shown in Figure 8 are attributed to the effect of segregation. When the backfilled columns are short (e.g., $10 \mathrm{~cm}$ and $20 \mathrm{~cm}$ high), segregation occurs within very limited space for the migration of fines (including cement). The effect of segregation on UCS are thus insignificant. As the backfilled columns become longer, the migration of fine particles and cement can be more significant. The loss of cement near the bottom leads to very low strength while the accumulation of cement near the top results in much higher strength than other parts of the fill mass.

\section{Degree of Segregation}

The variations of the particle size distribution curves shown in Figure 5 along with the distribution of $D_{50}$ shown in Figure 6 clearly indicate the occurrence of segregation within CHF. Several standards have been proposed to measure the degree of segregation resistance, mainly including the assessment of static segregation for self-consolidated concrete using penetration test in the field [73] and using column technique in the laboratory [39]. The former consists of measuring the settlement of coarse particles of concrete through the penetration depth of a tube in a filled container. This penetration depth allows to estimate qualitatively the degree of segregation resistance: resistant, moderately 
resistant, or not resistant. The latter refers to the comparison of the masses of coarse particles at the bottom and top of a column, expressed as [39]:

$$
\begin{gathered}
S=\frac{2\left(C A_{B}-C A_{T}\right)}{C A_{B}+C A_{T}}, \quad \text { if } C A_{B}>C A_{T} \\
S=0, \quad \text { if } C A_{B} \leq C A_{T}
\end{gathered}
$$

where $S$ is the static segregation, and $C A_{T}$ and $C A_{B}$ are the masses of coarse aggregates at the top and bottom sections of the column, respectively.

However, these qualitative methods for describing the segregation (including Equation (1)) neglect the effect of the deposition methods, the dynamic displacement of the fine particles (and its content), and space (distance) variation of different size particles. To overcome (partly) these limitations, the following expression is proposed to quantitatively define the degree of segregation $D S$ of a backfill placed in an opening:

$$
D S=\frac{\sum_{i=1}^{N}\left|D_{50 . i}-D_{50.0}\right|}{\sum_{i=1}^{N} \Delta l_{i}}
$$

where $N$ is the number of surveys; $\Delta l_{i}$ is the distance increment; $D_{50.0}$ is the $D_{50}$ of the initial slurried backfill; $D_{50 . i}$ is the $D_{50}$ of the slurried backfill at the $i$ th point of survey.

By applying Equation (2), the distribution of the $D S$ can be obtained along the elevation of each column.

Figure 9 shows the distribution of the DS with the elevation for the columns of $40 \mathrm{~cm}$ and $80 \mathrm{~cm}$, respectively. The average $D S$ values are also plotted on the figure, with $4.6 \mu \mathrm{m} / \mathrm{cm}$ (or $\left.4.6 \times 10^{-4}\right)$ and $7.1 \mu \mathrm{m} / \mathrm{cm}$ (or $7.1 \times 10^{-4}$ ) for the columns of $40 \mathrm{~cm}$ and $80 \mathrm{~cm}$, respectively. In general, the settled backfill shows high degree of segregation near the bottom (Elevation $0 \mathrm{~cm}$ to $20 \mathrm{~cm}$ for both columns) and the highest DS value near the top (Elevation $30 \mathrm{~cm}$ to $40 \mathrm{~cm}$ for $40-\mathrm{cm}$-high column, and $70 \mathrm{~cm}$ to $80 \mathrm{~cm}$ for $80-\mathrm{cm}$-high column), and the smallest DS value close to the mid-height (Elevation $20 \mathrm{~cm}$ to $30 \mathrm{~cm}$ for both columns) of the samples. These results are straightforward. During the drainage and consolidation of slurried backfill, coarse particles settle down and fine particles move upward while the particles of intermediate sizes can move down or up or even remain immobile, depending on the particle size and the upward draining water flow. This results in a fill mass with more coarse particles near the bottom and more fine particles near the top of the backfill. More specifically, as the column base is undrained, the bottom part receives a large portion of coarse particles with some trapped fines, leading to relatively high $D S$ value. Near the top, most coarse particles move downward while the finest particles arrive with the upward flow, resulting in a fill mass having a $D_{50}$ much smaller than that of the initial backfill as illustrated in Figure 6. This explains the highest degree of segregation near the top of columns shown in Figure 9. The lowest degree of segregation close to the mid-height is attributed to the interference between the upward movement of fines and downward migration of coarse particles as well as the indecisive movement of intermediate particles.

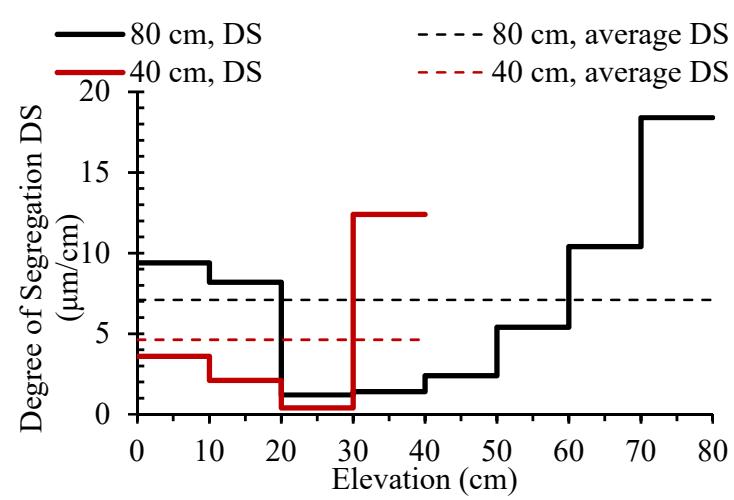

Figure 9. Variation of the degree of segregation (DS) along the height of settled backfill for columns of $40 \mathrm{~cm}$ and $80 \mathrm{~cm}$, respectively; the elevation was measured from the bottom of the columns. 
It is interesting to note that the pattern of the degree of segregation observed in the backfilled columns correlate well with the UCS distribution shown in Figure 8. Equation (2) seems to be reasonable to quantitatively describe the degree of segregation for $\mathrm{CHF}$.

\section{Discussion}

The segregation of CHF is investigated using samples prepared and cured in Plexiglas columns. The occurrence of segregation and its effect on the physical and mechanical properties of the settled backfill have been investigated. However, the test program includes the following limitations.

In this study, Plexiglas columns of $5 \mathrm{~cm}$ in diameter have been used to obtain standard cylinder samples of the CHF for the uniaxial compressive tests. With such columns of small diameter, an arching effect can take place during the self-weight consolidation of the slurried backfill. More tests can be done with larger diameter columns to investigate the size effect on the physical and mechanical properties of the backfill.

It is noted that the test program only involved one recipe with one particle size distribution, one solid content, and one cement content. More tests are thus needed to investigate the influence of these factors on the degree of segregation and physical and mechanical properties of the CHF.

In this study, no drainage was allowed through the base of columns. The drainage occurred toward the surface of the backfill. This led to loss of fine particles and cement near the bottom but accumulation of fine particles and cement near the top for the columns of $40 \mathrm{~cm}$ and $80 \mathrm{~cm}$. These results can be representative of backfilled stopes when the barricades are impervious or when the draining systems are inefficient. Otherwise, drainage can take place toward the top and the bottom. Apart from the migration of fine particles and cement, the drainage through the barricades may also lead to loss of fine particles and binders [74]. More tests are needed to see the influence of base drainage on the degree of segregation and resulting spatial variation of the physical and mechanical properties of the fill mass.

During the unconfined compressive tests, two types of failures are generally observed: diagonal shear (Figure 10a) and vertical split (Figure 10b). For a given formulation, Liu et al. [22] have shown that the specimens generally exhibit higher UCS under diagonal shear failure mode than under vertical split failure mode. In this study, however, the samples at the bottom of the backfilled columns showed diagonal shear failure mode (Figure 10a), while all the samples taken from the top showed vertical split failure mode (Figure 10b). As the top samples contain much more cement than the base samples, the top samples are much stronger than the base samples although the former exhibits split failure while the latter exhibits diagonal shear failure.

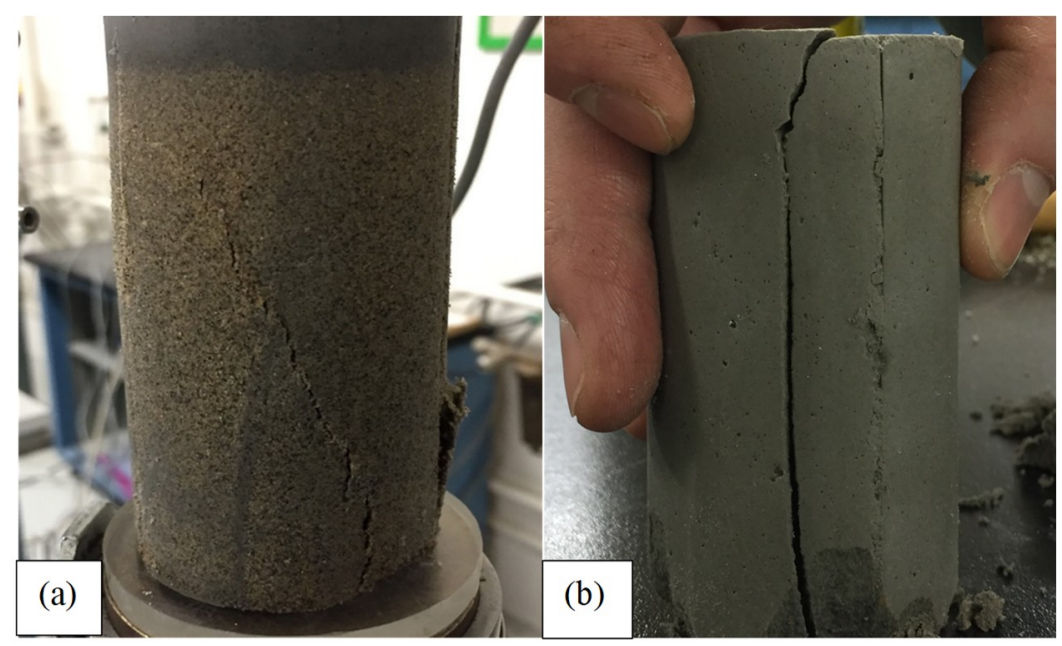

Figure 10. Typical failure modes of cylindrical cemented hydraulic fill (CHF) samples under uniaxial compression: (a) diagonal shear, (b) vertical split (or columnar split). 
In this study, Equation (2) has been proposed to quantitatively describe the degree of segregation $D S$. Only the spatial variation of $D_{50}$ was considered here to have a simple definition of $D S$. More representative expressions can be defined by including other key parameters, such as $D_{10}$, $D_{30}, D_{60}$, and even $C_{\mathrm{u}}$ and $C_{\mathrm{c}}$ of the material.

In mining backfills, the degree of consolidation is seldom considered. Rather, one usually refers a curing period of $7,14,28$, and 56 days. In this study, the tested backfill is a hydraulic backfill and the hydraulic conductivity is relatively high (around $2.4 \times 10^{-6} \mathrm{~m} / \mathrm{s}$ ). A curing period of 28 days can be estimated as long enough for the cemented backfill to reach a full self-weight consolidation. This is partly confirmed by the thicknesses of the settled backfill, estimated using an analytical solution of Yang and Li [67], developed for estimating the final ponding height at the top surface a hydraulic backfill at the end of self-weight consolidation. However, as the degree of segregation depends on the degree of self-weight consolidation, more work is needed to investigate the relationship between these two key aspects of the backfill.

Finally, the results presented above indicated that the strength tests with standard samples of $5 \mathrm{~cm}$ in diameter and $10 \mathrm{~cm}$ high may not be representative of the strength of fill mass in backfilled stopes with CHF. More work is needed to establish a model that can be used to estimate the strength distribution of the fill mass placed in the stopes.

\section{Conclusions}

Upon deposition of the $\mathrm{CHF}$, segregation of fill particles takes place and significantly influences the physical and mechanical properties of the backfill placed in openings. However, there are few studies on the characterization of the distribution of mechanical property within hydraulic fill due to segregation. It is particularly uncommon to quantify the spatial variation of the segregation and the resulting geotechnical properties after a backfill is placed in an opening. There is also a gap in quantitatively characterizing the degree of segregation using an appropriate expression or definition. In order to fill these gaps, laboratory tests were performed with different heights of samples prepared in Plexiglas columns. A part of the experimental results is presented in the paper. The main findings are summarized as follows:

- When the sample columns are short, segregation can take place, but the migration of fine particles and cement is restricted within a limited space. The effect of the segregation on the mechanical properties is not significant.

- When the samples columns are high, the migration of fine particles and cement can significantly affect the spatial distribution of the physical and mechanical properties of the settled backfill.

- The results also indicate that the UCS tests performed with standard samples of $5 \mathrm{~cm}$ in diameter and $10 \mathrm{~cm}$ high can provide a good estimation for the most part of the large samples. However, it can largely overestimate the strength of the bottom part and underestimate the strength of the top part of the fill mass when the hydraulic backfill is confined in an opening under base-undrained conditions. This represents the case where the backfill is placed in a mine stope with an undrained barricade.

- This work paves the way for establishing a model that can be used to estimate the spatial distribution of the strength of fill mass settled in a mine stope.

- An expression (Equation (2)) has been for the first time proposed to quantitatively describe the degree of segregation $D S$ of hydraulic backfill. The good agreement between the DS pattern defined by Equation (2) and the UCS distribution tends to indicate that the proposed definition is adequate to quantify and qualify the segregation of hydraulic backfill.

- More work is necessary by considering varying materials and base-drainage conditions.

Author Contributions: Data curation, J.B.D.; Formal analysis, J.B.D., L.L. and P.Y.; Funding acquisition, L.L.; Investigation, J.B.D., L.L. and P.Y.; Project administration, L.L.; Supervision, L.L.; Writing一original draft, J.B.D.; Writing—review \& editing, L.L. and P.Y. 
Funding: This research was funded by the Natural Sciences and Engineering Research Council of Canada (402318), Fonds de recherche du Québec-Nature et Technologies (2015-MI-191676), Mitacs Elevate Postdoctoral Fellowship (IT08484), and the industrial partners of the Research Institute on Mines and Environment (RIME UQAT-Polytechnique; http:/ / rime-irme.ca/).

Conflicts of Interest: The authors declare no conflict of interest.

\section{References}

1. Lamos, A.W.; Clark, I.H. The influence of Material composition and sample geometry on the strength of cemented backfill. In Proceedings of the Innovations in Mining Backfill Technology, Rotterdam, The Netherlands, 2-5 October 1989; pp. 89-94.

2. Hassani, F.; Archibald, J. Mine Backfill; CIM: Montreal, QC, Canada, 1998.

3. Potvin, Y.; Thomas, E.G.; Fourie, A.B. Handbook on Mine Fill; ACG: Perth, Australia, 2005.

4. Wang, M.; Liu, L.; Chen, L. Cold load and storage functional backfill for cooling deep mine. Adv. Civ. Eng. 2018. [CrossRef]

5. Wang, M.; Liu, L.; Zhang, X.Y. Experimental and numerical investigations of heat transfer and phase change characteristics of cemented paste backfill with PCM. Appl. Therm. Eng. 2019, 150, 121-131. [CrossRef]

6. Cao, S.; Yilmaz, E.; Song, W. Evaluation of Viscosity, Strength and Microstructural Properties of Cemented Tailings Backfill. Minerals 2018, 8, 352. [CrossRef]

7. Liu, L.; Fang, Z.Y.; Qi, C.C.; Zhang, B.; Guo, L.J.; Song, K. Experimental investigation on the relationship between pore characteristics and unconfined compressive strength of cemented paste backfill. Constr. Build. Mater. 2018, 179, 254-264. [CrossRef]

8. Lu, H.; Qi, C.; Chen, Q. A new procedure for recycling waste tailings as cemented paste backfill to underground stopes and open pits. J. Clean. Prod. 2018, 188, 601-612. [CrossRef]

9. Zhang, B.; Xin, J.; Liu, L. An experimental study on the microstructures of cemented paste backfill during its developing process. Adv. Civ. Eng. 2018. [CrossRef]

10. Zheng, J.; Li, L.; Li, Y. Total and effective stresses in backfilled stopes during the fill placement on a pervious base for barricade design. Minerals 2019, 9, 38. [CrossRef]

11. Yang, P.Y.; Li, L.; Aubertin, M.; Brochu-Baekelmans, M.; Ouellet, S. Stability analyses of waste rock barricades designed to retain paste backfill. Int. J. Geomech. 2017, 17, 04016079. [CrossRef]

12. Yang, P.; Li, L.; Aubertin, M. Stress ratios in entire mine stopes with cohesionless backfill: A numerical study. Minerals 2017, 7, 201. [CrossRef]

13. Yang, P.Y.; Li, L.; Aubertin, M. A new solution to assess the required strength of mine backfill with a vertical exposure. Int. J. Geomech. 2017, 17, 04017084. [CrossRef]

14. Yin, Y.; Zhao, T.; Zhang, Y.; Tan, Y.; Qiu, Y.; Taheri, A.; Jing, Y. An Innovative Method for Placement of Gangue Backfilling Material in Steep Underground Coal Mines. Minerals 2019, 9, 107. [CrossRef]

15. Zhang, J.; Li, M.; Taheri, A.; Zhang, W.; Wu, Z.; Song, W. Properties and Application of Backfill Materials in Coal Mines in China. Minerals 2019, 9, 53. [CrossRef]

16. Zhao, Y.; Soltani, A.; Taheri, A.; Karakus, M.; Deng, A. Application of Slag-Cement and Fly Ash for Strength Development in Cemented Paste Backfills. Minerals 2019, 9, 22. [CrossRef]

17. Zhang, J.; Deng, H.; Taheri, A.; Deng, J.; Ke, B. Effects of Superplasticizer on the Hydration, Consistency, and Strength Development of Cemented Paste Backfill. Minerals 2018, 8, 381. [CrossRef]

18. Nicholson, R.V.; Gillham, R.W.; Cherry, J.A.; Reardon, E.J. Reduction of acid generation in mine tailings through the use of moisture-retaining cover layers as oxygen barriers. Can. Geotech. J. 1989, 26, 1-8. [CrossRef]

19. Dobchuk, B.; Nichol, C.; Wilson, G.W.; Aubertin, M. Evaluation of a single-layer desulphurized tailings cover. Can. Geotech. J. 2013, 50, 777-792. [CrossRef]

20. Aubertin, M.; Bussière, B.; Bernier, L. Environnement et gestion des rejets miniers: Manuel sur cédérom; Presses Internationales Polytechnique: Montréal, QC, Canada, 2002.

21. Skrzypkowski, K.; Korzeniowski, W.; Poborska-Młynarska, K. Binding capability of ashes and dusts from municipal solid waste incineration with salt brine and geotechnical parameters of the cemented samples. Arch. Min. Sci. 2018, 63, 903-918. 
22. Liu, G.; Li, L.; Yao, M.; Landry, D.; Malek, F.; Yang, X.; Guo, L. An investigation of the uniaxial compressive strength of a cemented hydraulic backfill made of alluvial sand. Minerals 2017, 7, 4. [CrossRef]

23. Skrzypkowski, K. Compressibility of materials and backfilling mixtures with addition of solid wastes from flue-gas treatment and fly ashes. In Proceedings of the E3S Web of Conferences, Avignon, France, 4-6 June 2018. [CrossRef]

24. Bussière, B. Colloquium 2004: Hydro-geotechnical properties of hard rock tailings from metal mines and emerging geoenvironmental disposal approaches. Can. Geotech. J. 2007, 44, 1019-1052. [CrossRef]

25. Li, L.; Alvarez, I.C.; Aubertin, J.D. Self-weight consolidation of a slurried deposition: Tests and interpretation. Int. J. Geotech. Eng. 2013, 7, 205-213. [CrossRef]

26. Zheng, J.; Li, L.; Mbonimpa, M.; Pabst, T. An analytical solution of Gibson's model for estimating pore water pressures in accreting deposition of slurried material under one-dimensional self-weight consolidation. Part I: Pervious base. Ind. Geotech. J. 2018, 48, 72-83. [CrossRef]

27. Zheng, J.; Li, L.; Mbonimpa, M.; Pabst, T. An analytical solution of Gibson's model for estimating pore water pressures in accreting deposition of slurried material under one-dimensional self-weight consolidation. Part II: Impervious base. Ind. Geotech. J. 2018, 48, 188-195. [CrossRef]

28. Li, L.; Zheng, J. A conceptual analytical solution for estimating the short-term pressure of paste fill varying from viscous to liquid state, placed in mine stopes. In Proceedings of the 70th Years of Canadian Geotechnics and Geoscience, Ottawa, ON, Canada, 1-4 October 2017; pp. 643-650.

29. Thomas, E.G.; Nantel, L.H.; Notley, K.R. Fill Technology in Underground Metalliferous Mines; International Academic Services: Kingston, ON, Canada, 1979.

30. Rankine, K.J.; Sivakugan, N.; Cowling, R. Emplaced Geotechnical Characteristics of Hydraulic Fills in a Number of Australian Mines. Geotech. Geol. Eng. 2006, 24, 1-14. [CrossRef]

31. Sivakugan, N.; Rankine, K.; Lovisa, J.; Hall, W. Flow rate computations in hydraulic fill mine stopes. Ind. Geotech. J. 2013, 43, 195-202. [CrossRef]

32. Sivakugan, N. Drainage issues and stress developments within hydraulic fill mine stopes. Aust. J. Civ. Eng. 2008, 5, 61-70. [CrossRef]

33. Bates, R.C.; Wayment, W.R. Laboratory Study of Factors Influencing Waterflow in Mine Backfill-Classified Mill Tailings; Bureau of Mines: Washington, DC, USA, 1967.

34. Grice, A.G. Recent minefill developments in Australia. In Proceedings of the Minefill 2001: 7th International Symposium on Mining with Backfill, Seattle, WA, USA, 17-19 September 2001; pp. 351-357.

35. Rankine, K.J.; Sivakugan, N. Drainage characteristics and behavior of hydraulically placed mine fill and fill barricades. In Proceedings of the 16th International Conference on Soil Mechanics and Geotechnical Engineering, Osaka, Japan, 12-16 September 2005; Volume 2, pp. 579-582.

36. Sivakugan, N.; Rankine, K.J.; Rankine, K.S. Study of drainage through hydraulic fill stopes using method of fragments. Geotech. Geol. Eng. 2006, 24, 79-89. [CrossRef]

37. Brown, R.L. The fundamental principles of segregation. Inst. Fuel 1939, 13, 15-23.

38. Mosby, J.; Silva, S.R.D.; Enstad, G.G. Segregation of particulate materials mechanisms and testers. KONA Powder Part. J. 1996, 14, 31-43. [CrossRef]

39. ASTM C1610/C1610M-17. Standard Test Method for Static Segregation of Self-Consolidating Concrete Using Column Technique; ASTM International: West Conshohocken, PA, USA, 2017.

40. Khayat, K.H.; Guizani, Z. Use of viscosity-modifying admixture to enhance stability of fluid concrete. Mater. J. 1997, 94, 332-340.

41. Bui, V.K.; Montgomery, D.; Hinczak, I.; Turner, K. Rapid testing method for segregation resistance of self-compacting concrete. Cem. Concr. Res. 2002, 32, 1489-1496. [CrossRef]

42. Panesar, D.K.; Shindman, B. The effect of segregation on transport and durability properties of self consolidating concrete. Cem. Concr. Res. 2012, 42, 252-264. [CrossRef]

43. Nili, M.; Razmara, M.; Nili, M.; Razmara, P. Proposing new methods to appraise segregation resistance of self-consolidating concrete based on electrical resistivity. Constr. Build. Mater. 2017, 146, 192-198. [CrossRef]

44. Blight, G.E.; Thomson, R.R.; Vorster, K. Profiles of hydraulic-fill tailings beaches, and seepage through hydraulically sorted tailings. J. S. Afr. Inst. Min. Metall. 1985, 85, 157-161.

45. Blight, G.E. The master profile for hydraulic fill tailings beaches. Proc. Inst. Civil Eng. Geotech. Eng. 1994, 107, 27-40. [CrossRef]

46. Blight, G.E. Geotechnical Engineering for Mine Waste Storage Facilities; CRC Press: London, UK, 2009. 
47. Durand, R. Basic relationships of the transportation of solids in pipes-experimental research. In Proceedings of the International Association for Hydro-Environment Engineering and Research 5th Congress, Minneapolis, MN, USA, 1-4 September 1953.

48. De Korompay, V. Review of hydraulic transportation systems for mine backfill. EMR, Canada. Mines Branch Rep. 1974, 74, 118.

49. Turian, R.M.; Yuan, T.F. Flow of slurries in pipelines. Am. Inst. Chem. Eng. J. 1977, 23, 232-243. [CrossRef]

50. Li, M.; Bernier, L.; Boucher, J.F. Rheology of mineral pastes and its implications on underground pipeline delivery [CD-ROM]. In Proceedings of the Symposium 2002 on Environment and Mines, CIM, Rouyn-Noranda, QC, Canada, 29 April-2 May 2002.

51. Ouattara, D. Étude des propriétés rhéologiques de résidus miniers densifiés. Master's Thesis, École Polytechnique de Montréal, Montréal, QC, Canada, 2011.

52. Jerabek, F.; Hartman, H. Investigation of segregation and compressibility in discharged fill slurry. Trans. Soc. Min. Eng. 1965, 232, 18-23.

53. Corson, D.R. Laboratory Study of Effect of Cement and Dispersant Additives on Hydraulic Backfill; Report of Investigation No.6831; U.S. Dept. of the Interior, Bureau of Mines: Washington, DC, USA, 1966.

54. Corson, D.R. Stabilization of Hydraulic Backfill with Portland Cement: Including Results with Other Additives; Report of Investigation No.7327; U.S. Dept. of the Interior, Bureau of Mines: Washington, DC, USA, 1970.

55. Coates, D.F.; Yu, Y.S. Analysis of grading effects on hydraulic and consolidated fill. Can. Min. Metall. Bull. 1969, 62, 279-284.

56. Dickhout, M.H. The role and behaviour of fill in mining. In Proceedings of the Jubilee Symposium on Mine Filling, North West Queensland, Australia, 14-19 October 1973; pp. 1-11.

57. McNay, L.M.; Hill, J.R. The Strength of Cemented Hydraulic Sandfill Modified by Flocculants; U.S. Dept. of the Interior, Bureau of Mines: Washington, DC, USA, 1976.

58. Scoble, M.J.; Piciacchia, L. Hydraulic backfill design to optimize support and cost effectiveness. Min. Sci. Technol. 1986, 4, 75-85. [CrossRef]

59. Scoble, M.J. Ingénierie des remblais souterrains: Étude commandée par le Centre de recherches minérales; Centre de recherches minérales: Sainte-Foy, QC, Cananda, 1991.

60. Fourie, A.B.; Copeland, A.M.; Barrett, A.J. Optimisation of the as-placed properties of hydraulic backfill. J. S. Afr. Inst. Min. Metall. 1994, 94, 199-209.

61. Ouellet, J.; Bussière, B.; Gagnon, G. Simulation numérique du remblayage d'un chantier de mine avec du remblai hydraulique cimenté: Élaboration du modèle. In Proceedings of the 3rd Canadian Conference on Computer Applications in the Mineral Industry, Montréal, QC, Canada, 22-25 October 1995; pp. 331-339.

62. Cooke, R. Design procedure for hydraulic backfill distribution systems. J. S. Afr. Inst. Min. Metall. 2001, 101, 97-102.

63. Martic, Z.; Gelson, J.; Brás, H.; Xu, Q.; Brosko, W. New perspectives for cemented hydraulic fill with chemical technologies. In Proceedings of the Eleventh International Symposium on Mining with Backfill, Perth, Australia, 20-22 May 2014.

64. Yang, P.Y. Investigation of the Geomechanical Behavior of Mine Backfill and Its Interaction with Rock Walls and Barricades. Ph.D. Thesis, École Polytechnique de Montréal, Montréal, QC, Cananda, 2016.

65. Bardill, J.D.; Cenis, D.L. Studies of Several Flocculants to Improve Hydraulic Backfill Characteristics; Bureau of Mines: Washington, DC, USA, 1960.

66. Wang, C.; Tannant, H.D.; Padrutt, A.; Millette, D. Influence of admixtures on cemented backfill strength. Miner. Resour. Eng. 2002, 11, 261-270. [CrossRef]

67. Yang, P.Y.; Li, L. Evolution of water table and pore water pressure in stopes with submerged hydraulic fill. Int. J. Geomech. 2017, 17, 04017052. [CrossRef]

68. ASTM D5856-15. Standard Test Method for Measurement of Hydraulic Conductivity of Porous Material Using a Rigid-Wall, Compaction-Mold Permeameter; ASTM International: West Conshohocken, PA, USA, 2015.

69. Carraro, J.A.H.; Prezzi, M. A new slurry-based method of preparation of specimens of sand containing fines. Geotech. Test. J. 2007, 31, 1-11.

70. ASTM C39/C39M-12. Standard Test Method for Compressive Strength of Cylindrical Concrete Specimens; ASTM International: West Conshohocken, PA, USA, 2012.

71. Dalcé, J. Étude expérimentale des propriétés géotechniques d'un remblai hydraulique en lien avec la ségrégation des particules. Master's Thesis, École Polytechnique de Montréal, Montréal, QC, Canada, 2018. 
72. Sivakugan, N.; Rankine, K.; Rankine, R. Geotechnical aspects of hydraulic filling of underground mine stopes in Australia. Elsevier Geo-Eng. Book Ser. 2005, 3, 513-538.

73. ASTM C1712-17. Test Method for Rapid Assessment of Static Segregation Resistance of Self-Consolidating Concrete Using Penetration Test; ASTM International: West Conshohocken, PA, USA, 2017.

74. Yilmaz, E.; Belem, T.; Benzaazoua, M. Specimen size effect on strength behavior of cemented paste backfills subjected to different placement conditions. Eng. Geol. 2015, 185, 52-62. [CrossRef] 